\title{
Insulin secretion and food intake
}

\author{
By W. J. Malaisse, Laboratory of Experimental Medicine, Brussels University, \\ Brussels, Belgium
}

The stimulation of insulin release, which is required for the disposal of nutrients at the time of food intake (Cahill, I97I), appears to be the result of a joint excitation of the pancreatic $\beta$ cell by metabolic, hormonal and neural stimuli.

\section{Metabolic stimulation of insulin release}

Various metabolites are known to stimulate insulin release. As reviewed in detail elsewhere (Hager, Pipeleers, Herchuelz \& Malaisse, 1972), glucose and mannose are the only sugars which have consistently been found to exert a significant insulinotropic action. They are also the only sugars to stimulate insulin biosynthesis in the $\beta$ cell. The relationship between the rate of both insulin synthesis and release and the glucose concentration of the fluid bathing the $\beta$ cell is characterized by a sigmoidal curve, with a threshold value for the stimulant action of glucose at a concentration close to $5 \mathrm{mmol} / 1$ and a maximal response in the range $17-28 \mathrm{mmol} / 1$. The effect of mannose upon the processes of insulin synthesis and secretion is less marked than that of glucose. Mannose does not enhance the maximal effect of glucose on insulin secretion.

As recently reviewed (Fajans, Floyd, Knopf, Pek, Quibrera \& Conn, r971; Malaisse, I972a), various amino acids (especially lysine, arginine and leucine) and lipid metabolites (triglycerides, long- and short-chain fatty acids, and keto acids) also stimulate insulin secretion under appropriate experimental conditions. The ability of the lipid metabolites to stimulate insulin release might be conditioned by genetic and environmental factors.

Only in a few instances has the insulinotropic action of non-carbohydrate metabolites been systematically evaluated in vitro over the whole range of glucose concentrations. However, such an extensive investigation is required in order to characterize adequately whether a given agent should be considered as a glucosesimulating or glucose-potentiating insulinotropic factor (Malaisse, MalaisseLagae \& Brisson, 1971). In those instances in which this analysis was performed, for example with leucine and certain lipid metabolites, it was found that these substrates lower the threshold value for glucose-induced insulin release and might even stimulate secretion in the absence of glucose, but no stimulant action could be detected at high-glucose concentrations (Malaisse \& Malaisse-Lagae, r968). These features are characteristic of glucose-simulation. It is quite possible that other non- 
carbohydrate metabolites, for example arginine, do not behave in a comparable manner and are able to display a glucose-potentiating effect (unpublished observations).

Despite an increasing number of biochemical studies on isolated islets, little is still known about the mechanism by which glucose, leucine and other substrates stimulate insulin release. Immediate recognition of these metabolites by a cellular receptor, alteration in the cationic fluxes associated with their transport across the cell membrane, elaboration of a signal in the form of a derivative or cofactor linked with their intracellular metabolism are among the most commonly proposed explanations (Randle \& Ashcroft, 1970; Malaisse, I972a). Additional hypotheses include the activation of adenylcyclase by these metabolic substrates (Cerasi \& Iuft, I970), and a subtle theory implying both the recognition of the substrate and a modulatory influence of its intracellular metabolism (Renold, I970; Matschinsky, Ellerman, Krzanowski, Kotler-Brajtburg, Landgraf \& Fertel, 1971).

Within the limits of our present knowledge, all that can be advanced with a certain degree of confidence is that glucose, mannose and leucine, through any of the above-mentioned mechanisms, apparently provoke an accumulation of calcium in the $\beta$ cell. Indeed, these metabolites stimulate the net uptake of ${ }^{45} \mathrm{Ca}$ by isolated islets (Malaisse, Malaisse-Lagae, Baird \& Lacy, 197I). The glucose-induced accumulation of $\mathrm{Ca}$ might be due, in part at least, to an inhibitory effect of glucose on the transport of $\mathrm{Ca}$ outwards across the membrane of the $\beta$ cell (Malaisse, 1972b). $\mathrm{Ca}$, in turn, is thought to trigger insulin release by activating a microtubularmicrofilamentous system involved in the migration and emiocytosis of secretory granules (Malaisse, Malaisse-Lagae, Baird et al. r971; Malaisse, 1972b).

\section{Hormonal stimulation of insulin release}

The influence of gastro-intestinal hormones upon insulin secretion has been reviewed on several occasions (Dupre, Curtis, Waddell \& Beck, r969; Creutzfeldt, Feurle \& Ketterer, 1970; Malaisse, 1972a). Secretin, pancreozymin and enteroglucagon all stimulate insulin release. The insulinotropic action of enteroglucagon is apparently more marked and more prolonged than that of other gastro-intestinal hormones, and will be considered here in more detail.

Glucose stimulates the release of enteroglucagon by incubated pieces of rat jejunum (Zandomeneghi, Teale, Murphy \& Buchanan, 1972). Thus, it is tempting to speculate that enteroglucagon is an important component of the entero-insular axis.

Enteroglucagon, like pancreatic glucagon, probably activates the $\beta$ cell's adenylcyclase and, by doing so, provokes a cellular accumulation of adenosine- $3^{\prime}, 5^{\prime}$-cyclic monophosphate (cAMP). Indeed, pancreatic glucagon and enteroglucagon affect insulin release in a manner shared by all insulinotropic agents thought to increase the level of cAMP in the $\beta$ cell, that is isoproterenol, adrenocortotrophic hormone, thyroid-stimulating hormone, theophylline, caffeine, cAMP itself and its dibutyryl derivative. None of these agents is able to provoke a sustained secretion of insulin in the absence of glucose or at glucose concentrations below the threshold value for 
glucose-induced insulin release. They all markedly enhance glucose-induced insulin release at higher glucose levels $\left(\mathrm{I} \cdot 0-3^{\circ} \circ \mathrm{mg} / \mathrm{ml}\right)$, the increment in secretion rate induced by these agents being most marked at the highest glucose concentration (Malaisse \& Malaisse-Lagae, 1970). Pancreatic glucagon and enteroglucagon, like theophylline, also enhance leucine-induced insulin release. The dependency on glucose (or other metabolic substrates) demonstrated by these agents is underlined by the fact that the enhancing action of enteroglucagon and theophylline upon insulin release is abolished whenever glucose-induced insulin release is itself suppressed by metabolic inhibitors such as mannophetulose or 2-deoxyglucose (Malaisse, Malaisse-Lagae \& Mayhew, 1967).

These findings had first led to the opinion that cAMP might exert its insulinotropic action by facilitating glucose metabolism in the $\beta$ cell. However, such a concept is not supported by the following observations. Firstly, an enhancing effect of enteroglucagon or theophylline upon leucine-induced insulin release is seen in the absence of glucose. Secondly, theophylline also enhances sulphonylureainduced insulin release in the absence of glucose (Malaisse, Mahy, Brisson \& Malaisse-Lagae, 1972). Thirdly, the available biochemical findings do not suggest, as reviewed elsewhere (Brisson, Malaisse-Lagae \& Malaisse, 1972), that cAMP or related drugs excrt marked effects on glucose metabolism in isolated islets. And lastly, theophylline or dibutyryl-cAMP do not enhance glucose-induced Ca uptake by isolated islets incubated at high-glucose concentrations.

An alternative explanation for the insulinotropic action of cAMP is that this nucleotide provokes an intracellular translocation of $\mathrm{Ca}$ from an organelle-bound pool into the cytosol of the $\beta$ cell (Brisson et al. 1972). The accumulation of $\mathrm{Ca}$ in the cytosol could, in turn, enhance insulin secretion, providing that some other insulinotropic agent, such as glucose or leucine, is also present in order to prevent the outflow, across the cell membrane, of the $\mathrm{Ca}$ load first translocated in the cytosol. This concept is supported by the fact that glucose markedly reduces the theophyllineinduced outflow of ${ }^{45} \mathrm{Ca}$ from perifused islets. It would explain why cAMP and related drugs are unable to exert a significant insulinotropic action in the absence of glucose or leucine.

Assuming that enteroglucagon provokes an accumulation of cAMP in the $\beta$ cell, the above-mentioned findings suggest that the intestinal hormone would be better able to exert its insulinotropic action after food intake, namely at a time when the $\beta$ cell is simultaneously exposed to high concentrations of circulating nutrients, especially glucose and certain amino acids.

\section{Neural stimulation of insulin release}

The influence of the autonomous nervous system on insulin secretion has recently been reviewed (Malaisse, Malaisse-Lagae, Leclercq-Meyer \& Brisson, I97I; Malaisse, 1972a). It is known, from both in vitro and in vivo experiments, that cholinergic agents stimulate insulin release (Malaisse, Malaisse-Lagae, Wright \& Ashmore, 1967; Kaneto, Kajinuma, Kosaka \& Nakao, 1968). Vagal stimulation also provokes a release of insulin (Daniel \& Henderson, r 967 ; Frohman, Ezdinli \& 
Javid, 1967; Kaneto, Kosaka \& Nakao, 1967). The insulinotropic effect of cholinergic agents or vagal stimulation is antagonized by atropine. That such a neural stimulation of insulin release might be part of the physiological response to food intake is suggested by a number of recent observations. Firstly, there appears to be a cephalic phase of insulin secretion, since both imaginary food ingestion during hypnosis and the mere view and olfaction of a meal are accompanied by an increase in the level of circulating insulin (Goldfine, Abraira, Gruenewald \& Goldstein, 1970; Parra-Covarrubias, Rivera-Rodriguez \& Almaraz-Ugalde, 197r). Secondly, full atropinization minimizes the increase in insulinaemia after intestinal glucose loading, even when the sugar is administered intraduodenally in order to avoid the interference of a delayed gastric emptying (Nelson, Mackay \& Sheridan, 1968).

It is still unknown by which molecular mechanism cholinergic stimuli at the nerve endings surrounding the $\beta$ cell (Orci, Lambert, Amherdt, Cameron, Kanazawa \& Stauffacher, 1970) stimulate insulin secretion. However, in view of the fundamental role played by cations in the stimulus-secretion coupling process, it is likely that cholinergic agents provoke insulin release by changing the polarization of and the cationic fluxes across the membrane of the $\beta$ cell.

\section{Conclusion}

The experimental findings here briefly outlined suggest that the release of insulin after food intake is the result of a multifactorial stimulation of the $\beta$ cell by circulating nutrients, gastro-intestinal hormones and vagal impulses. It is suggested that these various stimuli integrate their regulatory influences through a common denominator, namely the concentration of $\mathrm{Ca}$ in the cytosol of the $\beta$ cell (Fig. I). The cytoplasmic

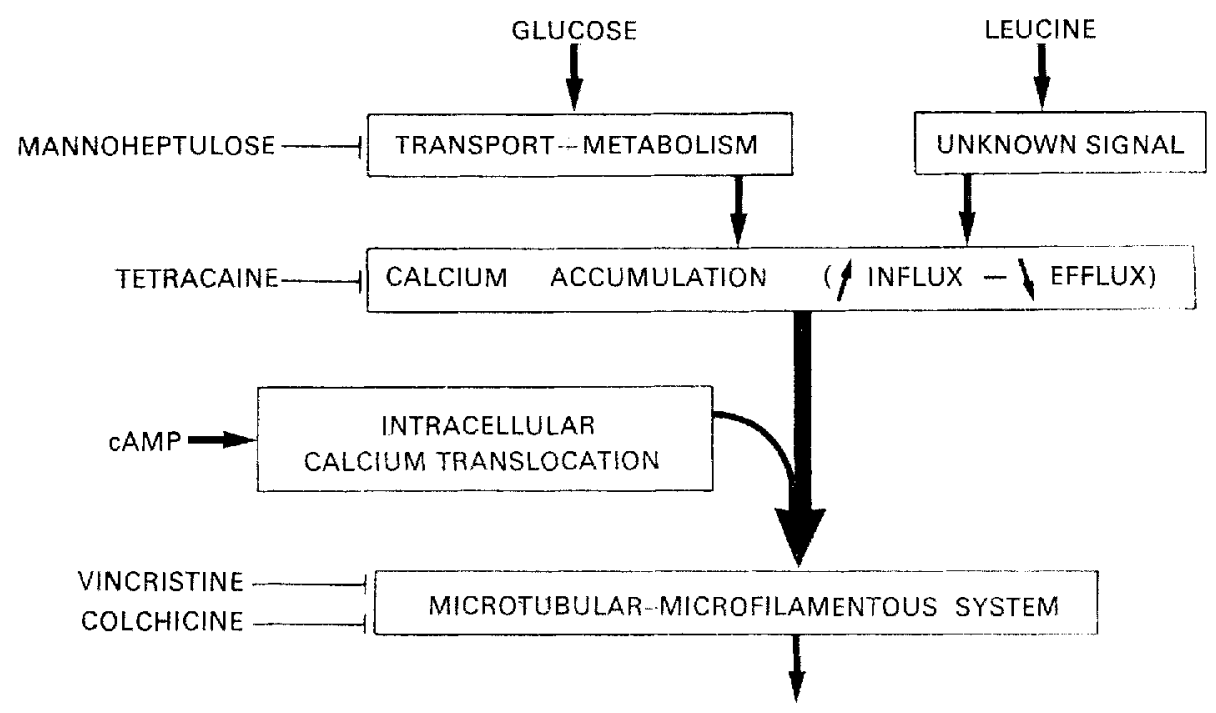

INSULIN RELEASE

Fig. I. A hypothetical model for the interaction of various insulinotropic agents in the $\beta$ cell. Also shown is the site of action of various inhibitors of insulin secretion. 
concentration of $\mathrm{Ca}$, in turn, might control the emiocytosis of insulin-secretory granules by regulating the activity of the $\beta$ cell's microtubular-microfilamentous system.

The experimental work here reviewed was supported in part by a grant from the Fonds de la Recherche Scientifique Médicale (Brussels, Belgium) and the association contract Euratom-Universities of Brussels and Pisa.

\section{REFERENCES}

Brisson, G. R., Malaisse-Lagae, F. \& Malaisse, W. J. (I972). F. clin. Invest. 5r, 232.

Cahill, G. F. Jr (1971). Diabetes 20, 785 .

Cerasi, E. \& Luft, R. (I970). Acta diabet. lat. 7, Suppl. no. 1, p. 278.

Creutzfeldt, W., Feurle, G. \& Ketterer, H. (ז970). Nezo Engl. F. Med. 282, г 139.

Daniel, P. M. \& Henderson, J. R. (1967). F. Physiol., Lond. 192, 317.

Dupre, J., Curtis, J. D., Waddell, R. W. \& Beck, J. C. (1969). Int. Congr. Ser. no. I84, p. 202. Amsterdam: Excerpta Medica Foundation.

Fajans, S. S., Floyd, J. C. Jr, Knopf, R. F., Pek, S., Quibrera, R. \& Conn, J. W. (x97 I). Int. Congr. Ser. no. 23r, p. 123. Amsterdam: Excerpta Medica Foundation.

Frohman, L. A., Ezdinli, E. Z. \& Javid, R. (1967). Diabetes r6, 443-

Goldfine, I. D., Abraira, C., Gruenewald, D. \& Goldstein, M. S. (1970). Proc. Soc. exp. Biol. Med. $\mathbf{I 3 3}, 274$ -

Hager, D., Pipeleers, D. G., Herchuelz, A. \& Malaisse, W. J. (1972). Acta med. scand. (In the Press.)

Kaneto, A., Kajinuma, H., Kosaka, K. \& Nakao, K. (1968). Endocrinology 83, 65 I.

Kaneto, A., Kosaka, K. \& Nakao, K. (1967). Endocrinology 8o, 53 o.

Malaisse, W. J. (1972a). In Endocrine Pancreas p. 237 [D. F. Steiner and N. Freinkel, editors]. Washington DC: The American Physiological Society.

Malaisse, W. J. (1972b). Israel Y. med. Sci. 8, 244.

Malaisse, W. J., Mahy, M., Brisson, G. R. \& Malaisse-Lagae, F. (1972). Eur. J. clin. Invest. 2, 85.

Malaisse, W. J. \& Malaisse-Lagae, F. (1968). I. Lab. clin. Med. 72, $43^{8}$.

Malaisse, W. J. \& Malaisse-Iagae, F. (I970). In The Structure and Metabolism of the Pancreatic Islets p. 435 [S. Falkmer, B. Hellman and I. B. Täljedal, editors]. Oxford: Pergamon Press.

Malaisse, W. J., Malaisse-Lagae, F., Baird, L. \& Lacy, P. E. (I97I). Int. Congr. Ser. no. 23 I, p. 443. Amsterdam: Excerpta Medica Foundation.

Malaisse, W. J., Malaisse-Lagae, F. \& Brisson, G. (1971). In Recent Hypoglycemic Sulfonylureas p. I 14 [U. C. Dubach and A. Bückert, editors]. Berne: Hans Huber.

Malaisse, W. J., Malaisse-Lagac, F., Leclercq-Meyer, V. \& Brisson, G. (197I). In Symposium de Diabétologie p. 11. Paris: Les Laboratoires Servier.

Malaisse, W. J., Malaisse-Lagae, F. \& Mayhew, D. (1967). F. clin. Invest. 46, 1724.

Malaisse, W., Malaisse-Lagac, F., Wright, P. H. \& Ashmore, J. (1967). Endocrinology 80, 975.

Matschinsky, F. M., Ellerman, J. E., Krzanowski, J., Kotler-13rajtburg, J., Landgraf, R. \& Fertel, R. (1971). F. biol. Chem. 246, 1007.

Nelson, J. K., Mackay, I. S. \& Sheridan, B. (1968). Int. Congr. Ser. no. I 57, p. 21 5. Amsterdam: Excerpta Medica Foundation.

Orci, L., Lambert, A. E., Amherdt, M., Cameron, D., Kanazawa, Y. \& Stauffacher, W. (1970). Acta diabet. lat. 7, Suppl. no. I, p. I84.

Parra-Covarrubias, A., Rivera-Rodriguez, I. \& Almaraz-Ugalde, A. (197 I). Diabetes 20, 800.

Randle, P. J. \& Ashcroft, S. J. H. (1970). Acta diabet. lat. 7, Suppl. no. I, p. I59.

Renold, A. E. (r97o). New Engl. F. Med. 282, i73.

Zandomeneghi, R., Teale, J. D., Murphy, R. F. \& Buchanan, K. D. (1972). Eur.F. clin. Invest. (In the Press.) 